\title{
On Presuming Innocence
}

\section{Is Duff's Civic Trust Principle in Line with Current Law, Particularly the European Convention on Human Rights?}

\author{
Geert Knigge
}

\section{A Fruitful Approach}

Duff advances the idea of different presumptions of innocence (hereafter: PoI), instead of just one. I agree that this 'relaxed approach' is a fruitful one. From an analytical point of view it is an advantage that we do not have to start from the assumption that there is only one single presumption. Once one accepts the possibility that our system of criminal law is governed by different PoI, the question of whether 'the presumption of innocence' should be read narrowly or broadly, vanishes. This approach also removes the need, as Duff puts it, to argue that the different PoI 'can be unified' into a single presumption. Instead, alternative PoI may differ from each other in many respects. Even the rationale behind these presumptions, I would add, could be different.

In my view, which may depart slightly from Duff's, this even applies to the interpretation of a specific provision, such as Article 6(2) of the European Convention on Human Rights (hereafter: the Convention or ECHR). Even here more than one presumption may be at work. As I will argue below, it is at least debatable whether the jurisprudence of the European Court of Human Rights (hereafter: the European Court or ECtHR) on Article 6(2) can be explained by the existence of a single PoI.

Building an awareness of differences also brings a problem to light. That is, the question of whether all these presumptions, given their differences, have much in common. Duff argues that the different presumptions 'will be connected to each other in a larger web of values.' That might be true, but this does not bring us much further. The same can be said, for instance, about the principle of respect for personal freedom (Art. 5 ECHR) and the principle of respect for private life (Art. 8 ECHR). They form part of a larger web of values, which find their expression in the Convention. The central element or underlying principle of this web of values can be found in 'the dignity and worth of the human person,' as the Universal Declaration of Human Rights has it. However, although Articles 5 and 8 ECHR are connected to each other via the concept of respect for human dignity, it is not very helpful to present the right to personal freedom as another right to privacy (or vice versa). The differences between these human rights far outweigh what they have in common. Therefore clear distinctions are needed to ascertain the proper scope and functioning of each of them. 
One of the questions I will address in this paper, is whether the 'civic PoI' to which Duff has given the floor, has much in common with Article 6(2) ECHR. It might be a bit mystifying to call this 'principle of civic trust,' if it exists at all, a presumption of innocence. Surely the differences call for a clear distinction?

A characteristic element of Duff's approach is that his analysis is rooted in existing systems of criminal law. Duff sets out to present, not theoretical concepts, but 'real' principles that underlie current positive law. In doing so, he confines himself, braving the reproach of parochialism, to common law systems, while also believing that his arguments should apply more broadly. His expectation is that what is true for common law systems makes sense for other liberal democracies as well. I agree with that, at least as far as states are concerned that are party to the ECHR. According to the Preamble to this Convention, these 'likeminded' countries have a 'heritage of political traditions, ideals, freedom and the rule of law' in common. It is hardly conceivable, if the principle of civic trust is indeed of a fundamental nature, that this principle does not have a place in this common heritage.

However, this approach makes Duff's analysis particularly susceptible to criticism. The question is whether the account he presents is true. Is there indeed a civic PoI that underlies the law as it stands? Do we need such a broad principle for a better understanding of our criminal law systems? I will argue that the answer is no.

I will start with an analysis of the case law of the European Court on Article 6(2) ECHR. This analysis has value in its own right, in that it shows that this case law can hardly be explained by one single PoI. More importantly, however, the analysis serves as a basis for criticism. I will argue that the approach Duff advocates is in tension with the Convention in several respects.

\section{Article 6(2) ECHR}

Article 6(2) ECHR provides that everyone charged with a criminal offence shall be presumed innocent until proven guilty according to law. This provision applies to 'everyone charged with a criminal offence.' So it follows from its wording that Article 6(2) is not limited to the trial phase. The presumption of innocence operates from the very moment a person is 'charged,' and this is normally a significant time before the trial starts. ${ }^{1}$ The presumption, as the European Court holds, is one of the 'constituent elements' of the right to a fair trial and is therefore closely linked to the other provisions of Article $6 .^{2}$ The right of the accused to have adequate time and facilities for the preparation of his defence (Art. 6(3)(b)) would hardly be appropriate if the accused is not to be presumed innocent in the pre-

1 According to the European Court a formal accusation is not a prerequisite for a criminal charge. Other measures 'which likewise substantially affect the situation of the suspect' might amount to a criminal charge as well. See, a.o., Foti and others v. Italy, app. no. 7604/76 ECtHR (1982), §52. 
trial phase. The same can be said about the right to legal assistance (Art. 6(3)(c)), which implies the right to access to a lawyer in the initial stages of the proceedings. These pre-trial rights can be seen as specific applications of the presumption of innocence.

This relatively wide scope of the presumption of innocence should not be mistaken for a broad reading of the provision as such. Article 6(2) contains a safeguard against arbitrary conviction. It makes clear that a person cannot be convicted unless his guilt is proven and that the burden of proof lies with the authorities. But this does not mean that the authorities are obliged to act as if the accused is not guilty. The judge must be impartial, but the prosecutor need not be, at least not at the trial stage of the proceedings. The core business of a prosecutor is indeed to charge a person with a criminal offence and to maintain at the trial that the defendant is guilty. This is not incompatible with the right to a fair trial and therefore not at odds with the presumption of innocence as one of its constituent elements. It is not even incompatible with the right to a fair trial and its constituent elements to impose a fine on a person before a trial is held. In Öztürk v. Germany, app. no. 8544/79 ECtHR (1984) the Court observed that

'conferring the prosecution and punishment of minor offences on administrative authorities is not inconsistent with the Convention provided that the person concerned is enabled to take any decision thus made against him before a tribunal that does offer the guarantees of Art. 6.'

As long as the right to a fair trial is upheld, so it seems, acting upon strong indications of someone's guilt is not inconsistent with the presumption of innocence. For similar reasons, pre-trial detention is not at variance with this presumption. According to Article 5(1)(c) ECHR a 'reasonable suspicion' forms a justification for such detention, provided that it is 'effected for the purpose of bringing [the suspect] before the competent legal authority.' This part of the article - read in conjunction with Article 5(3), which entitles the suspect to a speedy trial - means that the purpose of pre-trial detention is to ensure that the suspect will stand trial, which of course has to be fair. Thus pre-trial detention cannot normally be inconsistent with a fair trial because it supports this aim.

As shown above, a person's entitlement to be presumed innocent commences when that person is charged with a criminal offence. This presumption is a necessary safeguard, once the accusation has been made. It follows that the presumption presupposes a criminal charge, not in a matter-of-fact way ("bad things happen'), but as something lawful. ${ }^{3}$ It is also worth pointing out that the European Convention is not merely a negative undertaking, as the European Court has held on numerous occasions, but brings with it positive obligations as well. In Osman

3 The very nature of a safeguard implies that the act of power for which the safeguard is devised, is in itself in accordance with the law. It would be contradictory to introduce a safeguard to govern unlawful conduct. 
v. the United Kingdom, app. no. 23452/94 ECtHR (1998), § 115 for example, the Court noted that the State's primary duty in connection with Article $2 \mathrm{ECHR}$ is

'to secure the right to life by putting in place effective criminal law provisions to deter the commission of offences against the person backed up by lawenforcement machinery for the prevention, suppression and sanctioning of breaches of such provisions.'

Such law-enforcement machinery could hardly be considered effective if the possibility of pre-trial detention was not part of it.

To this primary duty comes 'in certain well-defined circumstances' an obligation 'to take preventive operational measures to protect an individual whose life is at risk from the criminal acts of another individual.' This is what the Osman case was about. The question was whether the police was to blame for not having prevented the killing of Ali Osman, who was the husband and father of the applicants. The Court, observing that 'the police must discharge their duties in a manner compatible with the rights and freedoms of individuals,' answered this question in the negative. It held ( $§ 121)$ that the police

'cannot be criticised for attaching weight to the presumption of innocence or failing to use powers of arrest (...) having regard to their reasonably held view that they lacked at relevant times the required standard of suspicion to use those powers (...).'

Notably, the Court refers to the PoI in spite of the fact that a criminal charge was absent. This seems to confirm Duff's proposition that more than one PoI is discernible. However, it should also be noted that arrest is, in the Court's view, not at odds with this seemingly broad PoI, provided that the required standard of suspicion is met. The rationale for this PoI may therefore be the protection of individuals against arbitrary interferences with their rights and freedoms. There must be a sufficient reason for such interference. If there is, then the presumption is not violated.

Similar references to the PoI are regularly made in the case law concerning Article 5(3) ECHR. Here, the persistence of a reasonable suspicion is only a condition sine qua non for the lawfulness of continued detention on remand. After a certain lapse of time there must be 'a genuine requirement of public interest justifying, with due regard to the principle of the presumption of innocence, a departure from the rule of respect for individual freedom." ${ }^{4}$ This reference to the PoI seems to hint, not at the requirement of a reasonable suspicion, but at something different. Pre-trial detention must not degenerate into punishment in advance. 
There are other glimpses of broader PoI (plural) in the case law of the European Court. In Sekanina v. Austria, app. no. 13126/87 ECtHR (1993) the Court held that Article 6(2) was violated in a situation in which the criminal charge had ended in a final acquittal and in which, for that reason, a safeguard against unsafe conviction was no longer needed. The Austrian courts had refused Sekanina's claim for compensation, arguing that the acquittal had not cleared Sekanina of all suspicion. The European Court, stressing at the outset that Article 6(2) does not guarantee a right to compensation when lawful detention on remand ends with an acquittal, stated ( $(30)$ that 'the voicing of suspicions regarding an accused's innocence' is conceivable during the criminal proceedings, but that 'it is no longer admissible to rely on such suspicions once an acquittal has become final.' One could speculate what the rationale behind this PoI is. There might be a connection with the requirement to respect verdicts and therefore with the ban on double jeopardy as laid down in Protocol 7, Article $4 .^{5}$

Although the voicing of suspicions during the proceedings is acceptable, courts have to restrain themselves in this respect. This became apparent in the Böhmer v. Germany judgment (app. no. 37568/97 ECtHR (2002)), in which the Court held (§54):

'The presumption of innocence will be violated if a judicial decision or a statement by a public official concerning a person charged with a criminal offence reflects an opinion that he is guilty before he has been proved guilty according to law.'

It follows that only the trial judge, in his verdict, may express a finding of guilt. This has a bearing on proceedings that coincide with a pending trial, such as pretrial detention proceedings. According to the Court ( $(67)$, the PoI 'excludes a finding of guilt outside the criminal proceedings before the competent trial court, irrespective of the procedural safeguards in such parallel proceedings.' Thus, although the pre-trial detention court has to establish that the required degree of suspicion is in place, neither its decision nor the supporting reasoning may suggest that the court regards the accused as guilty. The Court stressed 'the importance of the choice of words' in this respect ( $\$ 56$ ). In addition to this, it could be argued that the pre-trial court ought not to embark on a thorough investigation into the suspect's guilt. Such an investigation might suggest that the decision to

5 Art. 4(1) reads as follows: 'No one should be liable to be tried or punished again in criminal proceedings under the jurisdiction of the same State for an offence for which he has already been finally acquitted or convicted in accordance with the law and penal procedure of that State.' 
detain the suspect depends on it and may therefore easily lead to the impression that this decision reflects a finding of guilt. ${ }^{6}$

It is important to note that in the quotation above, from the Böhmer judgment, 'a judicial decision' and 'a statement by a public official' are bracketed together. So the same applies to both. This did not come as a surprise. In its Allenet de Ribemont v. France judgment (app. no. 15175/89 ECtHR (1995), § 36), the European Court had already pointed out 'that the presumption of innocence may be infringed not only by a judge or court but also by other public authorities.' In this case the Court found a breach of Article 6(2) because of remarks about the suspect's guilt made by the Minister of the Interior and two senior police officers at a press conference. ${ }^{7}$

It should also be noted that this quotation relates to a decision or statement 'concerning a person charged with a criminal offence.' So there must be a link with a pending trial. This is supported by the fact that, according to the European Court, the rationale for the requirement lies in 'preventing the undermining of the fairness of a criminal trial by prejudicial statements made in relation to those proceedings. ${ }^{8}$

The question is how these 'other' PoI found in the case law of the European Court relate to the civic PoI that Duff proposes. Are these presumptions derived from Article 6, with their seemingly different rationales, manifestations of an allembracing civic presumption? Or, in other words, can these presumptions be explained by 'the principle that citizens are entitled to be trusted'?

\section{Is There a Civic PoI?}

Duff's civic PoI differs from the presumptions outlined above in at least two major respects. First, this presumption is not confined to 'vertical' relations between public authorities and the individual. It covers the 'horizontal' relations between ordinary citizens as well. Second, this civic presumption is not restricted to the past. It presumes not only that a certain individual did not commit the crime he is suspected of, but also that he will not commit a crime in the future. Because of these huge differences, the broad reading of the PoI Duff advocates is not in any way supported by the case law of the European Court. Of course, this does not warrant the conclusion that a civic principle of trust has no place in the

6 The Böhmer v. Germany judgment concerns the revocation of a suspended prison sentence on the ground of (suspected) reoffending. The conclusion that the German Court of Appeal had breached Art. 6(2) ECHR by declaring the applicant guilty of a newly committed criminal offence was, as the European Court put it, 'further supported by facts that the Court of Appeal opted for the taking of evidence (...) and proceeded to a substantial and detailed evaluation of the probative value of the statements made by the witnesses in its decision.'

7 The prosecutor is a public authority as well. His statements at the trial are, I presume, excepted. The same applies to the imposition of a fine by an administrative authority. It can be argued that such imposition reflects the opinion that the suspect is guilty.

8 See, a.o., Maksim Petrov v. Russia, app. no. 23185/03 ECtHR (2012), § 102. 
current law. It is indeed possible that such a principle exists without the support of any obligation under the Convention. But the burden of proof lies with Duff. What evidence does he present for the existence of this trust principle?

As far as I can see, Duff does not offer any direct evidence. There is no mention of clauses in international conventions, of statutory provisions or of judicial decisions or observations which can be shown to express said principle. Moreover, Duff's reading of the state of Anglo-American law falls short of confirming that this law is governed by civic trust as a principle. In fact, I am inclined to take a contrary view.

When Duff considers 'ex-offenders,' he argues that 'in civilized systems' punishment has an end and that an offender who has completed his punishment, is entitled to be presumed innocent of crime again. His presumed innocence, says Duff, is 'restored.' This means, if I understand Duff correctly, that the crime he has committed, must be ignored completely. Even to call that person an offender, would, although his guilt is proven according to law, be at variance with the PoI. 'But,' Duff adds, ignoring the crime 'is not what happens.' He distinguishes three 'salient' types of legal consequence regularly attributed to a criminal conviction. Duff is very critical of this approach precisely because it does not correspond with the civic trust principle. In doing so he seems to embark on a crusade against the law as it stands and seeks to reform it and to bring it in line with the level of trust that, in his view, a convicted person is entitled to. According to Duff, all 'postpunishment preventive detention' would have to be abolished, at least in principle, including the English 'indeterminate sentence for public protection.' However, this provision is a measure that forms part of the sentence and therefore the necessary condition for the entitlement to be presumed innocent again (namely that the offender has completed his punishment) seems not to be fulfilled. One may wonder whether Duff's reasoning is based on certain retributive theories - in which preventive measures do not count as punishment - rather than with a PoI. But I will leave that aside. My point is, that all these inconsistencies with the civic trust principle that Duff stumbles upon, could hardly be presented as evidence that such a principle exists as part of the current law.

Similar remarks could be made about the way Duff treats pre-trial detention. Here again Duff advocates a law reform because in his view the law as it stands, infringes the civic trust principle. He also claims that the current law is in 'in tension' with the PoI that operates at the trial. The reason for this being that the court's pre-trial decision 'must be affected by its judgment of how likely it is that he [the defendant] is guilty.' If Duff gives a true description of Anglo-American law by saying that the denial of bail is 'significantly affected' by the likelihood that the defendant is guilty, then indeed the PoI might easily be violated. For, as we saw above, Article 6(2) ECHR is breached if pre-trial detention is tantamount to punishment or if a pre-trial decision reflects a finding of guilt. The courts must refrain from an assessment of the suspect's guilt and confine themselves to the compelling reasons that may justify pre-trial detention. That is the kind of reform 
Duff should advocate, provided that his account of Anglo-American law is correct. $^{9}$

The reason why, according to Duff, detention on remand is 'clearly inconsistent' with the civic PoI, is that such detention means that we treat the suspect 'as someone who simply cannot be trusted.' In this respect there is, still according to Duff, a difference with the granting of bail, for in the latter case the defendant is, because of the 'reassurances' he has given us, trusted not to flee, not to interfere with the trial process, and not to reoffend. Whether this representation of the difference between detention on remand and bail is a convincing one, is a question I will address later. First I want to draw attention to some of the modifications Duff deems necessary to bring the law into line with the civic trust principle.

Duff advocates a system of bail 'that treats all defendants (...) equally.' The decisions should no longer be based 'on the court's judgment about how likely the individual defendant is to flee.' To avoid a violation of the civic PoI, the court must, as I understand it, steer away from the 'particular defendant' and attach the suspicion to 'the role' the defendant has to play. If these are not just words, but rules for practical application, then the court could no longer give due weight to the particular circumstances of each individual suspect brought before it. This however, would be inconsistent with Article 5(3) ECHR. The European Court has constantly held that the courts

'must examine all the circumstances arguing for or against the existence of a genuine requirement of public interest [justifying pre-trial detention] and set them out in their decisions on the applications for release. ${ }^{10}$

Admittedly, this relates to detention, but granting bail is governed by the same basic principle. ${ }^{11}$ In the case of M.B. v. Poland for instance, the Court considered that 'the amount of bail must be assessed principally with reference to the accused, his assets and his relationships with persons who are to provide the security.' A refusal to take personal information into account, therefore contravenes Article 5(3) ECHR. ${ }^{12}$

9 I am not an expert in English law, so I do not venture on an opinion about the way s. 4, Schedule 1, Part 1, para. 9 of the Bail Act 1976 (mentioned by Duff in n. 46), should be interpreted. I dare say, however, that in Dutch law a stronger suspicion is needed for prolonged pre-trial-detention than for the initial arrest (in that sense the 'strength of the evidence' is an important factor), but that the courts are not allowed to go any further than to establish that the required degree of suspicion is met.

10 See, e.g., Kemmache v. France, app. no. 12325/86 ECtHR (1991), § 45.

11 Not surprisingly so. The question whether detention on remand is justified, is in the case law of the European Court closely linked with the question whether conditional release is possible as an alternative measure to secure the legitimate aims pursued.

12 M.B. v. Poland, app. no. 11887/07 ECtHR (2011), § 35. See also Neumeister v. Austria, app. no. 1936/63 ECtHR (1968), § 14. 
Another law reform urged by Duff concerns the almost complete abolition of pretrial detention. Such detention may only be justified in 'exceptional cases,' on condition that, inter alia, the court 'has very strong evidence that the defendant is guilty of the crime charged.' Two remarks could be made here. First, it is far from exceptional that an accused may lack the financial resources necessary to pay an amount of bail sufficient to deter him from absconding. According to Duff, however, this does not, as a rule, justify pre-trial detention. As is shown above, the State is under a positive obligation to put in place effective law-enforcement machinery, of which pre-trial detention is an indispensable element. Therefore, the proposed law reform would actually lead to a violation of the Convention. Second, by establishing, as a prerequisite for detention on remand, that there is 'very strong evidence' that the suspect is guilty, the court will breach Article 6(2) ECHR. As argued above, the presumption of innocence requires the court to refrain from an assessment of the suspect's guilt under all circumstances.

In conclusion, the evidence suggests that the full implementation of the civic trust principle will contravene the Convention in several respects. This finding strongly suggests in turn that this principle does not exist under the law in force, not even in a dormant form.

\section{Confusion of Fact and Law}

Duff introduces his trust principle at the end of section 2 in his debate with Laudan. According to Duff, we should reject Laudan's nuanced version of the PoI - including the role of the 'continuing suspect' - 'as inconsistent with how we should aspire to treat each other as fellow citizens.' I understand that a continuing suspicion is unacceptable because 'a modest kind of civic trust' is 'basic to citizenship in a well-functioning republic.' However, I do not think this a convincing argument.

First, it should be noted that this argument seems to serve, in the absence of any other evidence, as ultimate proof of the existence of a civic trust principle. However, the fact that Duff needs this principle to prove Laudan wrong, is no evidence that such a principle really exists. Laudan might be right or, alternatively, the concept of a continuing suspicion could be rejected on other grounds. I shall come back to that in the last section. Second, and perhaps more importantly, it does not follow from the 'fact' that trust is essential in a well-functioning society that citizens 'should' aspire to trust each other. From a sociological point of view it could be argued that trust plays a fundamental role in every society worth the name, but that does not mean that trust is prescribed by law. An obligation to trust is self-contradictory. Such an obligation seems to indicate that we do not really, by ourselves, trust our fellow citizens. Trust that is forced upon us by law would be no trust at all.

This mixing up of fact and law seems to pervade the whole argument. Duff states that we owe our fellow citizens (civic) trust. He substantiates this claim by point- 
ing out that this trust 'shows itself in our demeanour as we walk the streets.' But 'the fact that we do not usually cross the road to avoid others coming towards us,' does not warrant the conclusion that the law forbids us to cross the road in such a situation. Here again, from a sociological point of view it might be argued that trust plays a vital role in our everyday life. We are interdependent, so a profound distrust of other people will not carry us very far. Such distrust, once manifest, can easily backfire upon us. Thus for our own good we need to trust other people, at least in certain situations and to a certain degree. But to hold that the law prescribes trust and obliges us to act accordingly, is quite another thing. The fellow citizen who crosses the road to avoid us, does not act against the law, no matter how deeply insulted we may feel by his behaviour.

This does not imply that the law has nothing to do with trust. The crucial importance of trust in society is acknowledged in the various ways the law protects justified trust and penalizes breaches of confidence. It should be noted, however, that this legal protection is not without its limits. In Dutch law for instance one simple lie (such as: 'This detergent is the best there is') is not enough to constitute the offence of 'oplichting, ${ }^{13}$ the equivalent of fraud by false representation in English law. ${ }^{14}$ The reason for this is that trust verging on foolishness does not deserve protection by law. Some caution is expected of us in our dealings with other people. The following underlines this. The man we haven't avoided by crossing the street may offer to sell us a brand new DVD player, with the price tag still neatly affixed to it, at a substantially reduced price. By accepting the offer, we run the risk of being charged with handling stolen goods. Distrust is required in this situation. Acting upon the presumption that the seller is innocent runs counter to the law. ${ }^{15}$

\section{Normative Roles}

The confusion between fact and law culminates in the concept of 'normative roles' that carry with them 'duties and responsibilities.' Once again, from a sociological point of view it is perfectly sound to speak of the different roles people play in society. But to impute a normative status to these roles goes too far. In Duff's analysis, the 'normative role' operates as a vehicle for the introduction of all kinds of responsibilities, which have no clear basis in the law. Under this analysis, observations about how people normally behave, moral statements and, as may be the case, even personal views, are transformed into rules of law simply by proclaiming that they are part of the role someone has to play. For instance, according to Duff, a defendant is required, once convicted, to 'accept' the court's verdict if there are no grounds for appeal. Later in his analysis Duff adds that 'on 
some views' punishment is 'something that offenders ought themselves to undertake.' However, an obligation to accept the court's verdict is not vested in the law as it stands. A convict may still have the right to an out of time appeal, in order to overcome a miscarriage of justice.

Since the concept of a normative role assigned to the defendant is at the centre of Duff's argument, it is worth a closer look. Among the duties Duff attributes to this role is the duty to appear in court. I do not doubt that such a duty exists in common law systems, but I want to point out that such a duty is not a self-evident part of the role of the defendant. For example, in Dutch law the defendant is, as a rule, not obliged to appear in court. He may choose to be tried in his absence, with or without legal representation. An obligation to appear amounts to an interference with the rights and freedoms of the defendant, and for that very reason it requires a justification. Such an obligation may be deemed necessary in the interests of justice (or because of another pressing social need). Incorporating it within the 'role' of the defendant does not suffice.

Another element of the role of the defendant, according to Duff, is that the defendant 'is expected' to respond to the charge with a plea of 'guilty' or 'not guilty.' It is not quite clear whether Duff sees this expectation as a fact of life or as a duty on the part of the defendant. But if this expectation is normative, then the question arises whether this is compatible with the right to silence under Article 6(2) ECHR. In Duff's analysis, this kind of question tends to be overlooked.

This relates to a more general point. Under Article 6(2) ECHR the presumption of innocence is closely linked to the right not to incriminate oneself. As a result, the position of the accused in criminal proceedings can be characterized as free. The defendant may participate in the proceedings on an equal footing with the prosecution; he is free to choose his own line of defence, free to remain silent and free to deny the charge, even against better knowledge. With this freedom guaranteed under the Convention, it is hard to reconcile the concept of a normative role burdened with indistinct duties and ill-founded responsibilities. This is highlighted by the following.

Duff argues that a system of bail can be consistent with the civic PoI once it is understood that the defendant has acquired 'a new normative status' as a result of plausible evidence of criminal wrongdoing being laid against him. This somehow serves as a justification for requiring the defendant to 'reassure' us and to back up his reassurance by providing a financial bond or by accepting certain restrictions on his movements. Here, Duff turns the entitlement to be trusted into its opposite: an obligation to make sure that one is trustworthy, or to make, in Duff's words, one's 'law-abiding intentions manifest.' Please note that this responsibility to reassure us is based on the mere fact that we, although the defendant might be innocent, hold reasonable suspicions against him. Why not go one step further, one might wonder, and require the defendant to reassure us by providing evidence that he is not guilty? 
The construct of a responsibility on the part of a defendant 'to show respect' for his 'fellow citizen's legitimate anxieties,' is constrained and defies reality. Duff seems to overlook that this responsibility leaves the defendant with little choice. A refusal to post bail will almost certainly be met with pre-trial detention. So this forcing the defendant to post bail or to accept the restrictions on his movements amounts to a considerable interference with his rights and freedoms, which therefore requires sufficient justification. A general and unrestricted demand to be reassured can hardly be seen as a pressing social need that necessitates such interference, and certainly not in light of the freedom that Article 6 ECHR guarantees to the accused.

\section{Thoughts Are Free}

The law regulates our behaviour, not our private thoughts and inner feelings. The latter are free, as long as what we do or fail to do is in conformity with the law. Duff seems to neglect this fundamental principle. The PoI does not relate to what we personally presume about other people. It leaves us free to think our fellow citizen a criminal and to harbour deep feelings of mistrust against him. Because thoughts are free, the law cannot prescribe trust. This explains why there is no trace of a civic trust principle in the current law.

This applies to public officials as well. What they privately think does not contravene the PoI, provided they keep these thoughts to themselves. We saw that, according to the European Court, the PoI is about the choice of words. It is the voicing of suspicions that violates the Convention, not the entertaining of them. We also saw that the police, arresting someone without the required reasonable suspicion, act against the PoI. Here again, the harbouring of an unreasonable suspicion does not violate the presumption, but the acting upon it does. Of course, the police is, to a certain extent, required to have ill-founded suspicions. When a crime comes to light, the police must speculate about possible perpetrators and devise scenarios that point into the direction of potential suspects. The starting point of a criminal investigation is normally not the presumption that everybody is innocent, but, on the contrary, that everybody might have committed the crime. This professional distrust of other people is not inconsistent with Article 6(2) ECHR.

Even the trial judge may have his private thoughts about the guilt of the defendant. What is required of him, apart from not showing these thoughts, is not to act upon them, that is, not to base the verdict thereon. As long as he, notwithstanding his personal beliefs, keeps an open mind to the possibility that the defendant is innocent and as long as he does not mistake his beliefs for the required proof according to law, the PoI is not violated.

Since the PoI is not about thoughts, it does not seem right to say, as Duff does, that this presumption is 'trumped' by a guilty verdict. The PoI is not in any way affected by the act of declaring the accused guilty according to law. That presump- 
tion does not forbid such an act. For similar reasons it is beside the point to say that the presumption is 'qualified' when a person is arrested or charged on a reasonable suspicion of him having committed an offence. The arrest or the criminal charge does not constitute an act that contravenes Article 6(2) ECHR. Nor is there any need to construe an infringement of the PoI that can be made in exceptional circumstances. In this respect the PoI is dichotomous. It is either violated by an act or omission, or it is not violated. There is nothing in between.

\section{Concluding Remarks}

In the introduction I hinted that the PoI is embedded in a larger web of values. This provides an additional reason against embracing a broad, comprehensive presumption of civic trust. There is no need for that. Other, more or less related principles may be relied on to understand the current law and, if necessary, to take a critical stance towards it. When it comes to pre-trial detention for instance, Duff is partly right. There is, following the case law of the European Court on Article 5(3) ECHR, a preference for bail (or other forms of conditional release) over detention. However, this is not because there is a fundamental difference between the two (both are justified by the same legitimate aims). It is rather a matter of proportionality. If the aims pursued can be met by bail, then detention is not necessary and therefore not justified.

Duff proclaims the existence of a civic trust principle in response to Laudan's concept of a continuing suspicion. This concept is far from new. Actually, until the nineteenth century it was put to practice throughout the whole of continental Europe. ${ }^{16}$ When neither his guilt, nor his innocence could be proven, the accused was given an 'absolutio ab instantia.' This was a kind of conditional release, with various restrictions to the suspect's freedom attached to it. The proceedings against him could be resumed at any time that new evidence came up.

The French revolution brought an end to this practice. A final acquittal (and with that, the ban on double jeopardy) was no longer restricted to defendants whose innocence was proved. Instead, post-revolution, an accused whose guilt could not be proven was entitled to a final acquittal as well. The reason for this reversal was based on the fact that, as history had shown, being prosecuted is burdensome. The prosecution therefore must end when a realistic prospect of a conviction within a reasonable time ceases to exist. The rationale for this change is a weighing of interests. The interest of living a life without interference prevails over the interest that all perpetrators are brought to justice. In other words: a continuing prosecution is disproportionate to the aim pursued.

One reason why a criminal charge is burdensome is the negative impact on the reputation of the accused. This aspect of the burden must also end with any pros-

16 This is discussed in some detail in W.F. van Hattum, Non bis in idem; de ontwikkeling van een beginsel [Non bis in idem; the development of a principle] (Nijmegen: Wolf Legal Publishers, 2012). 
ecution. This explains why, as the European Court held in Sekanina v. Austria, voicing suspicions about the accused following a final acquittal contravenes the Convention. It is important to note that there is also a 'horizontal' dimension to this. The protection of the reputation or rights of others is a legitimate aim under the Convention that justifies restrictions on the freedom of speech such as civil and criminal remedies against defamation. Ordinary citizens must also refrain from voicing suspicions, not because they have to trust the ex-accused, but because they may not do him harm without good cause. Consequently, there is no need to rely on a principle of civic trust as grounds for rejecting Laudan's version of the PoI.

Finally, consider again the ex-offender. Is there (or should there be) a right to rehabilitation, as Duff holds? I do not think that the current law includes a 'full-blown' right. Nevertheless, there are at least some principles on which a level of protection for ex-offenders can be based. I will mention just two of them. The first is the right to privacy as expressed through the law on defamation. Under Dutch law, for instance, it is unacceptable to publish the names of defendants and convicts. Moreover, a person who states in public without good cause that someone else has committed a crime is liable to punishment for defamation, even if this statement is true. ${ }^{17}$ The second principle is that of equality before the law, laid down, inter alia, in Article 20 of the Charter of fundamental rights of the European Union. For example, in performing their duties, public officials must not normally discriminate between ex-offenders and others. Furthermore, the law has to be construed accordingly. Of course, this does not offer an absolute protection. There is sometimes good reason to discriminate. The perceived dangerousness of an ex-offender, for instance, may justify protective measures. As we saw, there may even be a positive obligation to that effect. However, in a democratic society, there must be a pressing social need in order to justify any interference with the rights and freedoms of an ex-offender.

17 See Art. 261 of the Penal Code. In common law systems the law on defamation offers, as far as I know, less protection. In England and Whales truth is always a defence. In the United States truth is not a defence for public disclosure of private facts, but the ban on such disclosures does not apply to information already exposed to the public eye (such as information about past crimes gathered from court records). 